Review

\title{
Functional Properties of Biopolymer-Based Films Modified with Surfactants: A Brief Review
}

\author{
Ahmad Adlie Shamsuri 1,*(D) and Siti Nurul Ain Md. Jamil 2,3,*(D) \\ 1 Laboratory of Biocomposite Technology, Institute of Tropical Forestry and Forest Products, \\ Universiti Putra Malaysia, UPM Serdang, Selangor 43400, Malaysia \\ 2 Department of Chemistry, Faculty of Science, Universiti Putra Malaysia, UPM Serdang, \\ Selangor 43400, Malaysia \\ 3 Centre of Foundation Studies for Agricultural Science, Universiti Putra Malaysia, UPM Serdang, \\ Selangor 43400, Malaysia \\ * Correspondence: adlie@upm.edu.my (A.A.S.); ctnurulain@upm.edu.my (S.N.A.M.J.)
}

Received: 3 July 2020; Accepted: 5 August 2020; Published: 26 August 2020

\begin{abstract}
An increase of environmental awareness recently has increased the interest of researchers in using of biopolymer-based films. The films have been prepared extensively by utilizing starch, carboxymethyl cellulose, chitosan, protein, gelatin, carrageenan, alginate, pectin, guar gum and pullulan. They are typically modified with surface-active agents (surfactants) such as glycerol monostearate, sucrose ester, sodium stearoyl lactate, sodium dodecyl sulfate, ethyl lauroyl arginate $\mathrm{HCl}$, Span 20 to 80, Tween-20 to 80 and soy lecithin for improving the functional properties of the films. In this brief review, two types of biopolymer-based films that prepared through casting method were categorized, specifically solution- and emulsion-based films. The four types of surfactants, namely non-ionic, anionic, cationic and amphoteric surfactants that are regularly used to modify biopolymer-based films are also described. The functional properties of the films modified with different types of surfactants are briefly reviewed. This study enhances the attraction of researchers in biopolymer-based films and the improvement of new concepts in this niche area.
\end{abstract}

Keywords: surfactant; biopolymer; film; functional properties

\section{Introduction}

Today—due to environmental concerns and growing of the biodegradable plastic industry — the use of biopolymer-based films in the food industry and food packaging has become a trend. The bio-based resources are also contributing to the growth of the industry since they are sustainable and renewable supplies. Biopolymers are polymeric biomolecules obtained from natural sources. Starch was commonly used for the preparation of biopolymer-based films [1,2]. Starch can be obtained from corn [3-6], potato [7-9], cassava [10,11], tapioca [12,13], sorghum [14], loquat seed [15], kudzu [16], wheat [6] and yellow pea [17]. On the other hand, carboxymethyl cellulose (CMC) [18,19], chitosan [20-24], protein [25-31], gelatin [32-36], carrageenan [37,38], pectin [39], guar gum [17,40] and pullulan [41] (chemical structures displayed in Figure 1) are also utilized in preparation of biopolymer-based films because of they are biodegradable, renewable, low-cost and abundance. The films also have moderate mechanical properties such as tensile strength and elongation at break [42]. However, they have high water vapor permeability character [43] and poor moisture barrier property [44]. 
(a)

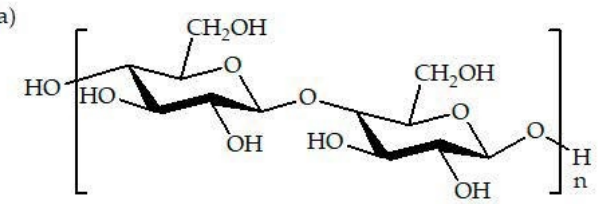

(c)

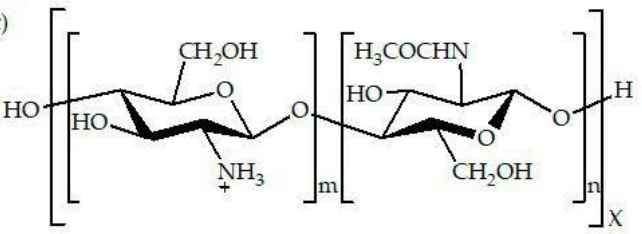

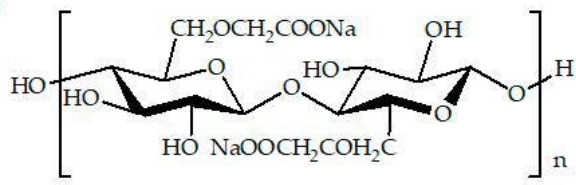

(d)

(f)

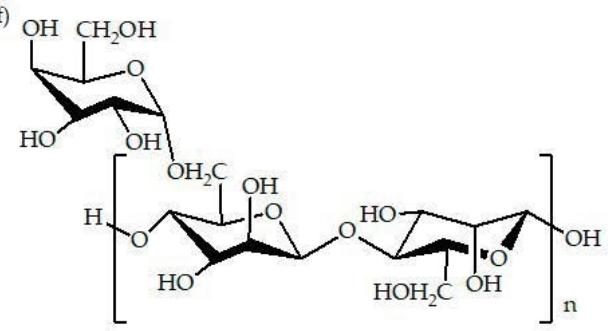

(e)

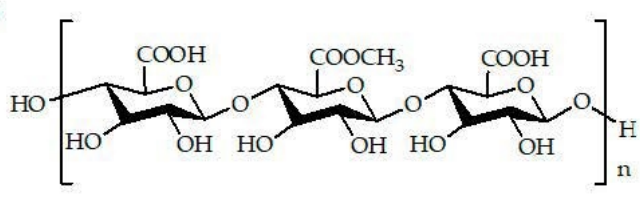

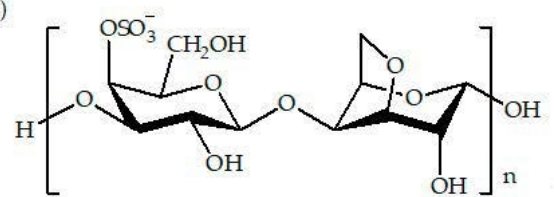

(g)

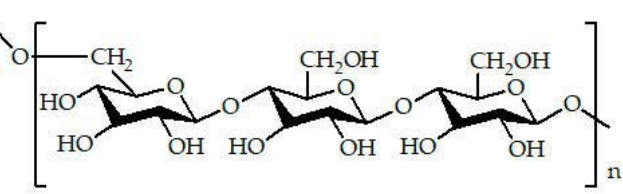

Figure 1. Chemical structures of (a) starch, (b) carboxymethyl cellulose (CMC), (c) chitosan [45], (d) carrageenan, (e) pectin, (f) guar gum and (g) pullulan.

Surface-active agents (surfactants) such as glycerol monostearate [3,5,46], sucrose ester $[1,39,47]$, sodium stearoyl lactate [39], sodium dodecyl sulfate [10], ethyl lauroyl arginate $\mathrm{HCl}$ [48,49], Span 20 to $80[2,5,6,16,50,51]$, Tween- 20 to $80[11,15,18,20,22,37,41,52]$ and soy lecithin $[2,27,28,31,43,53]$ (chemical structures indicated in Figure 2) are usually used as modifier for the biopolymer-based films. Surfactants possessed an amphiphilic character that has hydrophilic and hydrophobic properties [12]. The modification of the films by surfactants not only decreases water vapor permeability [24], but also improve the moisture barrier property of the films [51].

(a)

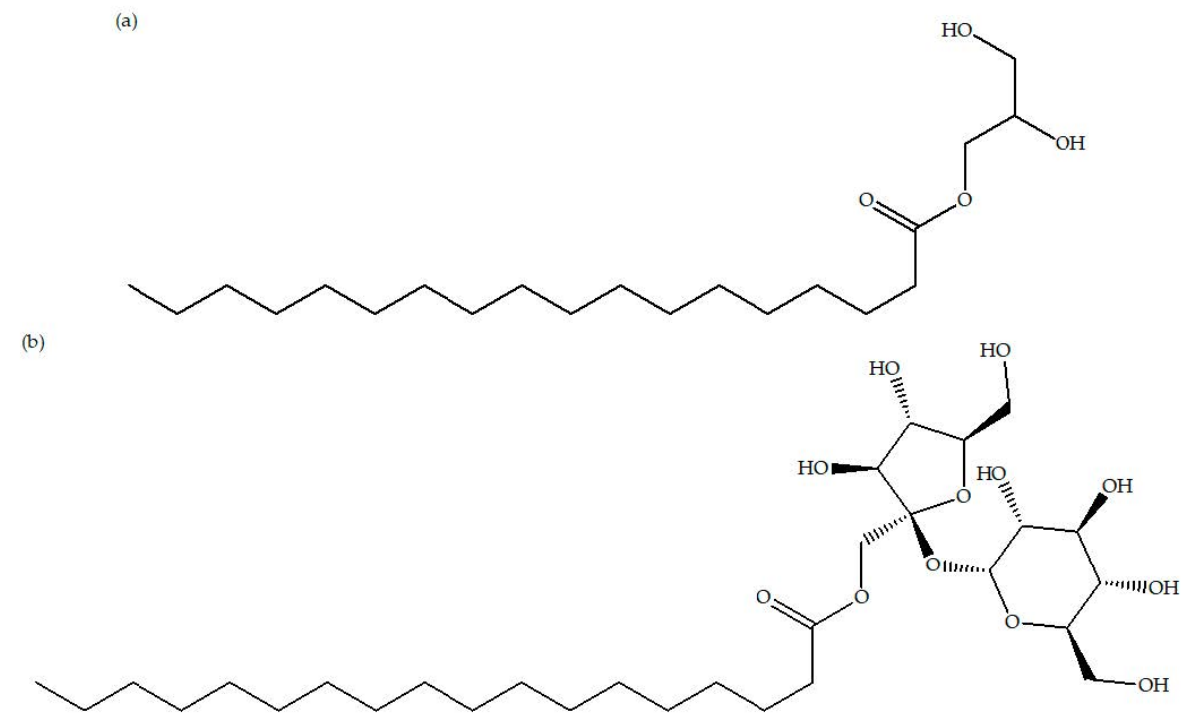

Figure 2. Cont. 
(c)

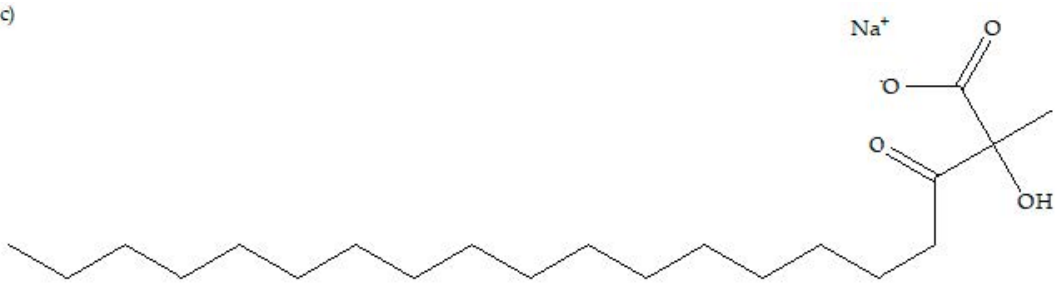

(d)<smiles>CCCCCCCCCCCCOS(=O)(=O)[O-]</smiles>

(e)<smiles>CCCCCCCCCCCC(=O)NC(CCCNC(=N)N)C(=O)OCC</smiles>

(f)<smiles>CCCCCCCCCCCC(=O)OCC(O)C1OCC(O)C1O</smiles>

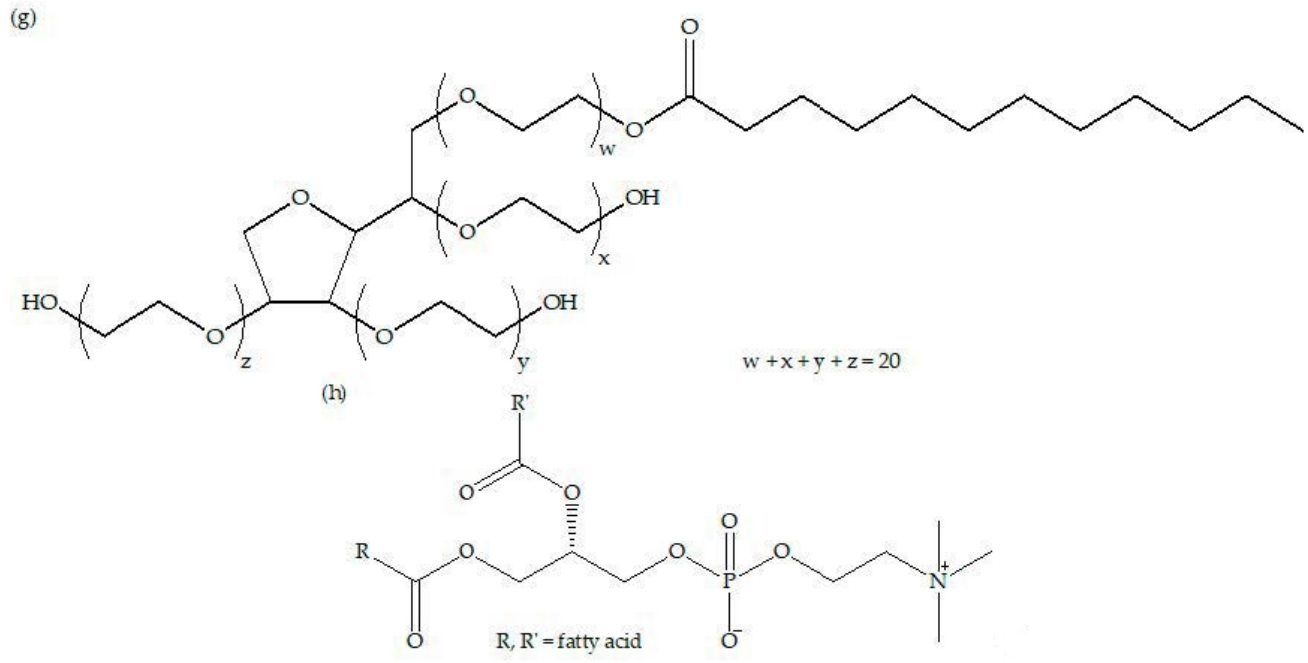

Figure 2. Chemical structures of (a) glycerol monostearate, (b) sucrose ester, (c) sodium stearoyl lactate, (d) sodium dodecyl sulfate, (e) ethyl lauroyl arginate $\mathrm{HCl}$, (f) Span 20, (g) Tween-20 and (h) soy lecithin.

In the last two decades, much research has been conducted with the objective of improving the functional properties (e.g., mechanical properties (tensile strength, elongation at break), water affinities (water vapor permeability, moisture content, solubility, swelling), contact angle, thermal stability, oxygen permeability and opacity) of biopolymer-based films by utilizing surfactants. Moreover, some works have concentrated on the emulsification for the preparation of biopolymer-based 
films. Nevertheless, to the best knowledge of the authors, no brief review has been created comprising the study on the preparation and modification of biopolymer-based films. This is the purpose of creating an organized review in this study.

\section{Types of Biopolymer-Based Films}

\subsection{Solution-Based Films}

Solution-based films are commonly prepared by dissolving a water-soluble biopolymer in the solvent such as water and heating at elevated temperatures with stirring to obtain a biopolymer solution. The attained solution is considered as film-forming solution (FFS) $[1,6,33,35,54]$. The solution casting technique is conducted by pouring the FFS into a flat-surfaced mold and drying in an oven or room temperature to acquire free-standing film [55]. The solution-based films are easy to prepare, and they are only required inexpensive tools. Table 1 shows the types of biopolymers, additional components and processing parameters of the films. The additional components such as glycerol, sorbitol and glucose (chemical structures exhibited in Figure 3) are typically added into the biopolymer solution to act as plasticizers for the prepared biopolymer-based films $[4,9,28]$. On the other hand, acetic acid and glucomannan function as a dissolving agent and a thickening agent for chitosan and pectin, respectively.

Table 1. Types of biopolymers, additional components and processing parameters of the solution-based films.

\begin{tabular}{|c|c|c|c|}
\hline Biopolymer & $\begin{array}{l}\text { Additional } \\
\text { Component }\end{array}$ & Processing Parameter & References \\
\hline Kudzu starch & Glycerol & $\begin{array}{l}3.0 \%(w / v) \text { of kudzu starch, } 0.9 \%(w / v) \text { of glycerol, } 100 \mathrm{~mL} \\
\text { of water, stirring at temperature of } 100{ }^{\circ} \mathrm{C} .\end{array}$ & [16] \\
\hline $\mathrm{CMC}$ & Glycerol & $\begin{array}{c}2.5 \mathrm{~g} / \mathrm{L} \text { of } \mathrm{CMC}, 5 \mathrm{~g} / \mathrm{L} \text { of glycerol, } 350 \mathrm{~mL} \text { of water, stirring } \\
\text { at temperature of } 60^{\circ} \mathrm{C} \text {. }\end{array}$ & {$[56]$} \\
\hline Chitosan & $\begin{array}{l}\text { Acetic acid, } \\
\text { glycerol }\end{array}$ & $\begin{array}{l}1 \mathrm{~g} \text { of chitosan, } 1 \mathrm{~g} \text { of acetic acid, } 20 \mathrm{~g} \text { of glycerol, } 100 \mathrm{~mL} \\
\text { of water, stirring at room temperature }\left(25 \pm 1^{\circ} \mathrm{C}\right) .\end{array}$ & {$[24]$} \\
\hline Gelatin & Glycerol & $\begin{array}{c}3.5 \mathrm{~g} \text { of gelatin, } 30 \mathrm{wt} \% \text { of glycerol, } 90 \mathrm{~mL} \text { of water, stirring } \\
\text { at temperature of } 70^{\circ} \mathrm{C} \text {. }\end{array}$ & [57] \\
\hline Pectin & Glucomannan & $\begin{array}{l}1 \%(w / v) \text { of pectin, } 0.75 \%(w / v) \text { of glucomannan, } 100 \mathrm{~mL} \text { of } \\
\text { water, stirring at room temperature }\left(25 \pm 1{ }^{\circ} \mathrm{C}\right) .\end{array}$ & [39] \\
\hline Guar gum & Glycerol & $\begin{array}{l}0.3 \mathrm{~g} \text { of guar gum, } 25 \mathrm{wt} \% \text { of glycerol, } 100 \mathrm{~mL} \text { of water, } \\
\text { stirring at temperature of } 40^{\circ} \mathrm{C} \text {. }\end{array}$ & [17] \\
\hline Pullulan & Glycerol & $\begin{array}{l}2 \%(w / v) \text { of pullulan, } 15 \mathrm{wt} \% \text { of glycerol, } 100 \mathrm{~mL} \text { of water, } \\
\text { stirring at temperature of } 45^{\circ} \mathrm{C} \text {. }\end{array}$ & {$[41]$} \\
\hline $\begin{array}{l}\text { Loquat seed } \\
\text { starch }\end{array}$ & Sorbitol & $\begin{array}{l}3.5 \%(w / v) \text { of loquat seed starch, } 45 \%(w / w) \text { of sorbitol, } \\
100 \mathrm{~mL} \text { of water, stirring at temperature of } 95^{\circ} \mathrm{C} \text {. }\end{array}$ & [15] \\
\hline Starch/chitosan & $\begin{array}{l}\text { Glycerol, } \\
\text { glucose }\end{array}$ & $\begin{array}{c}1.5 \%(w / v) \text { of starch/chitosan, } 1 \%(w / v) \text { of glycerol or } \\
\text { glucose, } 100 \mathrm{~mL} \text { of water, stirring at temperature of } 90{ }^{\circ} \mathrm{C} \text {. }\end{array}$ & [9] \\
\hline
\end{tabular}
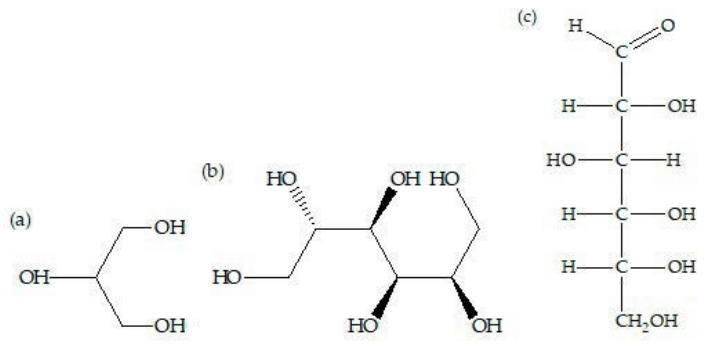

Figure 3. Chemical structures of (a) glycerol, (b) sorbitol and (c) glucose. 


\subsection{Emulsion-Based Films}

Emulsion-based films are generally prepared by making FFS first (as described in Section 2.1). After this, oil containing surfactant is made by inserting surfactant into the oil and then it is added into the FFS, followed by homogenizing to attain film-forming emulsion (FFE) [8,35,36,43,50]. The film is obtained by casting the FFE into glass plates and drying at elevated temperature or ambient temperature [21], unless stated differently in Table 2. Table 2 indicates the types of biopolymers, plasticizers, oils, surfactants and processing parameters of the films. Unlike solution-based films, emulsion-based films require oil for example, palm oil, beeswax, candelilla wax, virgin coconut oil, cinnamon bark oil and soybean oil to form emulsions [1,21,34,44,55]. The presence of hydrophobic substance such as oil can increase the elongation at break and decrease the water vapor permeability of the films [35,36]. The surfactants such as soy lecithin, sucrose ester (sucrose stearate), sodium dodecyl sulfate, Tween and Yucca schidigera extract (YSE) frequently modified the biopolymer emulsions by stabilizing the emulsions and retain homogeneity of the films [15,19]. Moreover, the emulsion-based films have lower water vapor permeability and higher elongation at break than the solution-based films as control film $[8,29,36,41,43,54]$.

Table 2. Types of biopolymers, plasticizers, oils, surfactants and processing parameters of the emulsion-based films.

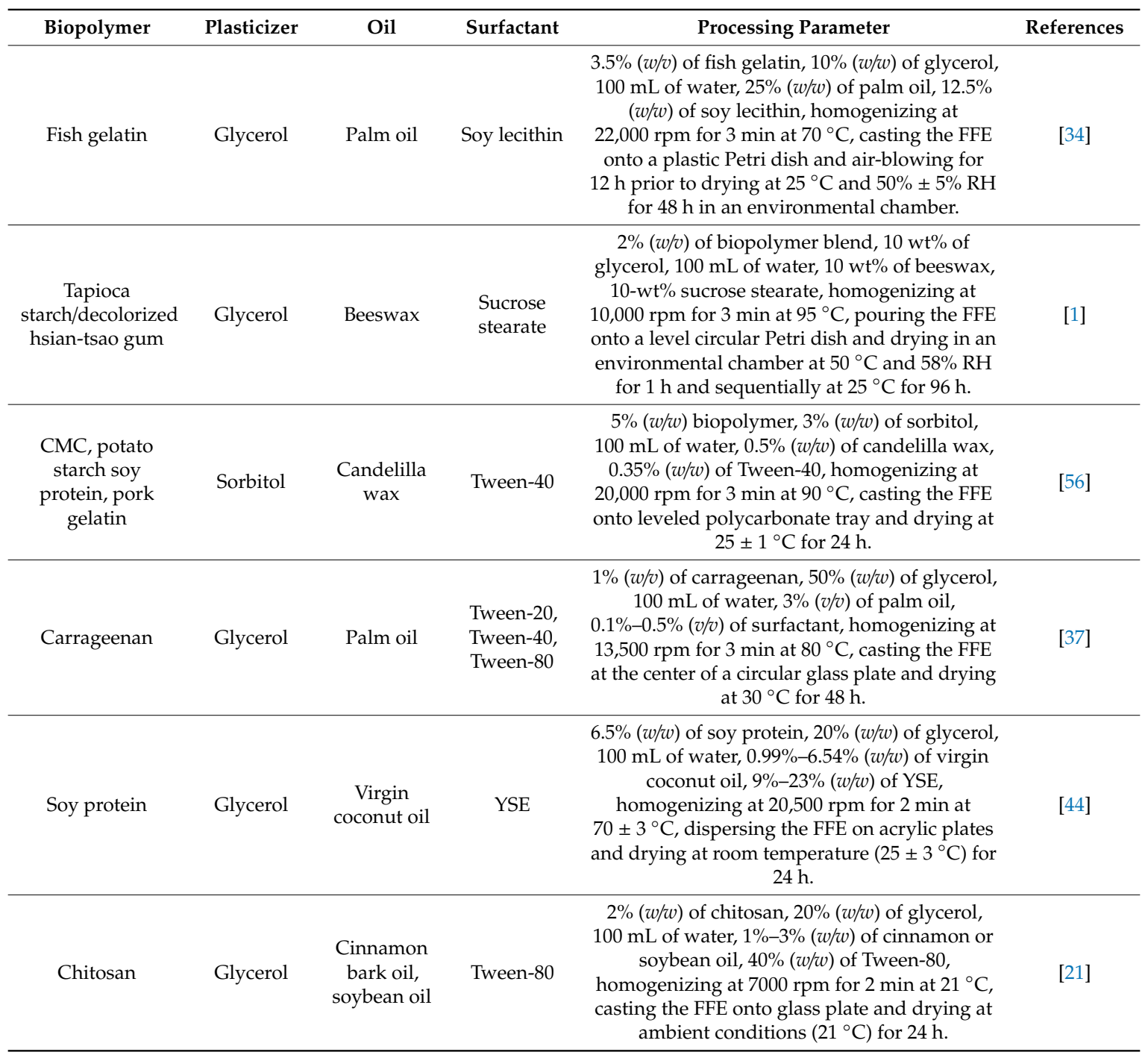


Table 2. Cont.

\begin{tabular}{|c|c|c|c|c|c|}
\hline Biopolymer & Plasticizer & Oil & Surfactant & Processing Parameter & References \\
\hline Gelatin & Glycerol & Palm oil & Tween-80 & $\begin{array}{l}3.9 \mathrm{wt} \% \text { of gelatin, } 33 \mathrm{wt} \% \text { of glycerol, } 100 \mathrm{~mL} \\
\text { of water, } 36 \mathrm{wt} \% \text { of palm oil, } 20 \mathrm{wt} \% \text { of } \\
\text { Tween- } 80 \text {, homogenizing at } 12,000 \mathrm{rpm} \text { for } \\
3 \text { min at } 60{ }^{\circ} \mathrm{C} \text {, casting the FFE evenly over a } \\
\text { rimmed acrylic plate and drying at } 25^{\circ} \mathrm{C} \text { in a } \\
\text { convection chamber for } 48 \mathrm{~h} .\end{array}$ & [36] \\
\hline Soy protein & Glycerol & $\begin{array}{c}\text { Virgin } \\
\text { coconut oil }\end{array}$ & Soy lecithin & $\begin{array}{l}6.5 \%(w / w) \text { of soy protein, } 20 \%(w / w) \text { of glycerol, } \\
100 \text { mL of water, } 0.99 \%-6.54 \%(w / w) \text { of virgin } \\
\text { coconut oil, } 9 \%-23 \%(w / w) \text { of soy lecithin, } \\
\text { homogenizing at } 20,500 \mathrm{rpm} \text { for } 2 \text { min at } \\
70 \pm 3{ }^{\circ} \mathrm{C} \text {, pouring the FFE on acrylic plate and } \\
\text { drying at } 25 \pm 3{ }^{\circ} \mathrm{C} \text { for } 24 \mathrm{~h} \text {. }\end{array}$ & [27] \\
\hline Fish gelatin & Glycerol & Palm oil & $\begin{array}{l}\text { Tween-20, } \\
\text { soy lecithin, } \\
\text { sodium } \\
\text { dodecyl } \\
\text { sulfate }\end{array}$ & $\begin{array}{l}3.7 \mathrm{wt} \% \text { of fish gelatin, } 30 \mathrm{wt} \% \text { of glycerol, } \\
90 \mathrm{~mL} \text { of water, } 50 \mathrm{wt} \% \text { of palm oil, } 25 \mathrm{wt} \% \text { of } \\
\text { surfactant, homogenizing at } 22,000 \mathrm{rpm} \text { for } \\
3 \mathrm{~min} \text { at } 70{ }^{\circ} \mathrm{C} \text {, casting the FFE onto a rimmed } \\
\text { silicone resin plate and air-blowing for } 12 \mathrm{~h} \text { at } \\
28-30{ }^{\circ} \mathrm{C} \text { prior to further drying at } 25^{\circ} \mathrm{C} \text { and } \\
50 \% \pm 5 \% \text { RH for } 24 \mathrm{~h} \text { in an } \\
\text { environmental chamber. }\end{array}$ & [43] \\
\hline
\end{tabular}

\section{Modification by Different Types of Surfactants}

\subsection{Types of Surfactants}

Generally, surfactants are classified into four types: non-ionic, anionic, cationic and amphoteric. The classification is based on the polarity of the surfactant head group, for example, non-ionic, anionic, cationic and amphoteric or zwitterionic. There is no charge on a head group of non-ionic surfactants, while anionic and cationic surfactants have negative and positive charges on their head groups, respectively. On the other hand, there are both negative and positive charges for the amphoteric surfactants. Table 3 displays the types of surfactants and film-forming used in the preparation of biopolymer-based films. The non-ionic surfactants such as Span and Tween are widely used in the preparation of solution- or emulsion-based films [2,5,55,56]. Moreover, another non-ionic surfactant, for instance, sucrose ester has also been used for the preparation of such films $[1,51]$. Instead, some anionic surfactants, for example, sodium stearoyl lactate and sodium dodecyl sulfate are commonly employed in the preparation of solution-based films by using gelatin and starch as polymer matrices [10,39]. The cationic and amphoteric surfactants such as ethyl lauroyl arginate $\mathrm{HCl}$ and soy lecithin could be utilized for both solution- and emulsion-based films [28,35,48,58].

Table 3. Types of surfactants and film-forming used in the preparation of biopolymer-based films.

\begin{tabular}{cccc}
\hline Surfactant & Type of Surfactant & Film-Forming & References \\
\hline Span 20 to 80 & Non-ionic & Solution/Emulsion & {$[2,5,16,47]$} \\
Tween-20 to 80 & Non-ionic & Solution/Emulsion & {$[20,21,37,55]$} \\
Sucrose ester & Non-ionic & Solution/Emulsion & {$[1,51,59]$} \\
Sodium stearoyl lactate & Anionic & Solution & {$[39]$} \\
Sodium dodecyl sulfate & Anionic & Solution & {$[10,30]$} \\
Ethyl lauroyl arginate HCl & Cationic & Solution/Emulsion & {$[48,49,58]$} \\
Soy lecithin & Amphoteric & Solution/Emulsion & {$[2,28,35,43]$} \\
\hline
\end{tabular}

\subsection{Modification by Non-Ionic Surfactants}

Table 4 shows examples of non-ionic surfactants, hydrophilic-lipophilic balance (HLB) values, alkyl chain length and functional properties of biopolymer-based films. Most of the non-ionic surfactants such as Span, Tween and sucrose ester are used in the preparation of biopolymer-based films $[1,5,6]$. Span and Tween with high HLB values have slightly shorter alkyl chain-length than low HLB values, 
whereas sucrose ester that have the same alkyl chain length possess different HLB values (Table 4). The HLB reveals the attraction of surfactant to water or oil. The HLB values can be calculated via Davies' method as in the equation below:

HLB $=7+\sum$ (hydrophilic group numbers) $+\sum$ (lipophilic group numbers)

For example, Span 40 or sorbitan monopalmitate (chemical structure presented in Figure 4).

$\mathrm{HLB}=7+\sum$ (group number of sorbitan) $+\sum$ (group number of $\mathrm{CH}_{2}$ and $\mathrm{CH}_{3}$ )

$\mathrm{HLB}=7+(6.8)+(15 \mathrm{x}-0.475)$

$\mathrm{HLB}=7+(6.8)+(-7.125)$

$\mathrm{HLB}=6.675$

$\mathrm{HLB} \approx 6.7$

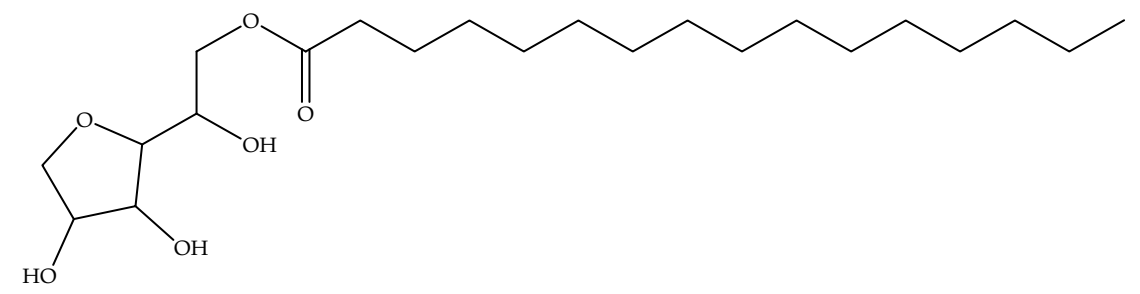

Figure 4. Chemical structure of Span 40.

Table 4. Examples of non-ionic surfactants, hydrophilic-lipophilic balance (HLB) values, alkyl chain length and functional properties of biopolymer-based films.

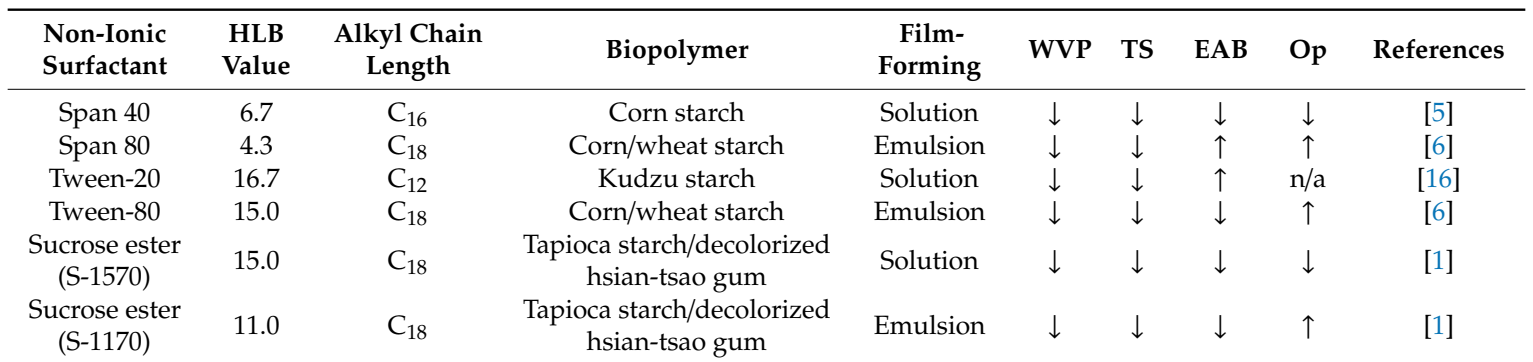

WVP—water vapor permeability, TS—-tensile strength, EAB—elongation at break and Op—opacity; The symbol $\uparrow$ corresponds to an increase in the properties and $\downarrow$ a decrease in the properties while "n/a" means "not available".

The higher the HLB values are, the larger the attraction to water is and the smaller the HLB values are, the larger the attraction to oil is [20]. Span 40 has an HLB value of 6.7 which is higher compared to Span 80 which has an HLB value of 4.3, thus, Span 40 was frequently used in the preparation of solution-based films [5], whereas Span 80 is considered as hydrophobic surfactant, it was utilized in the creation of emulsion-based films [6]. On the other hand, Tween-20 (has an HLB value of 16.7) and Tween-80 (has an HLB value of 15.0) have also been used in solution- and emulsion-based films, respectively $[6,16]$. The same trend was observed for sucrose ester as well, whereby sucrose ester with high HLB value was utilized in the preparation of solution-based films and vice versa [1].

Table 4 also shows that Span 40 has modified the FFS of corn starch in the preparation of the corn starch-based films [5]. The modification by Span 40 improves the functional properties such as water vapor permeability (WVP) and opacity (Op) of the films. The WVP of the films decreases by up to $30 \%$ compared to the film without Span 40 . This is attributed to the enhancement in the tortuosity factor for mass transport in the corn starch [5]. In addition, the transparency of the films is slightly decreased by up to $0.8 \%$ due to the existence of distributed surfactant aggregates, with a dissimilar refractive index, which increases the light scattering effect. The lower transparency suggests that the films are opaquer. Moreover, the tensile strength (TS) and elongation at break (EAB) of the films decrease by up to $57 \%$ and $12 \%$, respectively compared to the film without Span 40 . This is because of the creation of an additional anisotropic structure with decreased cohesion forces [5]. On the other hand, Span 80 modifies the FFE of corn/wheat starch containing essential oil in the preparation of the 
emulsified corn/wheat starch films [6]. The modification by Span 80 improves the functional properties such as WVP, EAB and Op of the films. The WVP of the films decreases by up to $17 \%$ compared to the corn/wheat starch film. This is attributed to Span 80, which is a hydrophobic surfactant with lower HLB value and cannot interact with water or corn/wheat starch [6]. Moreover, the EAB of the films slightly increases by up to $7.3 \%$ also because of the hydrophobicity of Span 80 which can have less effect on the intermolecular hydrogen bonding within starch-starch, consequently resulting in the increase of EAB. Furthermore, the Op of the films is significantly increased by up to $186 \%$ due to the hydrophobicity of Span 80 as well, which cannot lead to uniform structure with corn/wheat starch. However, the TS of the films decreases by up to $26 \%$ compared to the corn/wheat starch film. This result proves that Span 80 plays a major impact on the reduction of TS value [6].

Tween-20 modifies the FFS of kudzu starch in the preparation of the kudzu starch-based films [16]. The modification by Tween-20 has improved the functional properties such as WVP and EAB of the films. The WVP of the films is slightly decreased by up to 7\% compared to the film without Tween-20. The low decrease of WVP is attributed to the inherent hydrophilic property of Tween-20 [16]. In addition, the EAB of the films is significantly increased by up to $65 \%$ due to Tween-20 acted mechanically as plasticizer. However, the TS of the films is decreased by up to $35 \%$ compared to the film without Tween-20, this behavior is similar with the high flexibility films [16]. On the other hand, Tween-80 modifies the FFE of corn/wheat starch containing essential oil in the preparation of the emulsified corn/wheat starch films [6]. The modification by Tween-80 improves the functional properties such as WVP and Op of the films. The WVP of the films decreases by up to $11 \%$ compared to the corn/wheat starch film. The low decrease of WVP is attributed to Tween-80 is a hydrophilic surfactant with higher HLB value and can interact with water or corn/wheat starch [6]. In addition, the Op of the films has significantly increased by up to $193 \%$ due to the hydrophilicity of Tween- 80 as well, which can lead to uniform structure with corn/wheat starch. However, the TS and EAB of the films are decreased by up to $28 \%$ and $12 \%$, respectively compared to the corn/wheat starch film. This is because Tween-80 interacts with corn/wheat starch which weakens the intermolecular hydrogen bonding, subsequently resulting in the decrease of mechanical properties [6].

Sucrose ester (S-1570) or sucrose stearate modifies the FFS of tapioca starch/decolorized hsian-tsao gum in the preparation of the starch/gum-based films [1]. The modification by S-1570 has only improved the functional properties such as WVP of the films. The WVP of the films is decreased by up to $54 \%$ compared to the film without S-1570. This is attributed to the hydrogen bonding interaction between starch/gum and polar groups of S-1570, which reduces the number of polar groups free to interact with water molecules [1]. Nevertheless, the Op of the films is slightly decreased by up to $5.2 \%$ due to S-1570 can dissolve in FFS with individual molecules or micelles of the nanometers size and interact with amylose of starch and gum. Additionally, the TS and EAB of the films have decreased by up to $48 \%$ and $19 \%$, respectively compared to the film without S-1570. This is because S-1570 has an HLB value of 15, has more hydrophilic functional groups to interact with tapioca starch and hsian-tsao gum and hindered the interaction between starch and gum chains [1]. On the other hand, sucrose ester (S-1170) modifies the FFE of tapioca starch/decolorized hsian-tsao gum containing beeswax in the preparation of the emulsified starch/gum films [1]. The modification by S-1170 has improved the functional properties such as WVP and Op of the films. The WVP of the films is decreased by up to $24 \%$ compared to the starch/gum film. This is attributed to the presence of beeswax, which also enhances the water barrier property. Moreover, the Op of the films has significantly increased by up to $155 \%$ because of the formation of beeswax globules of the micrometers size in the FFE during the drying process [1]. Nevertheless, the TS and EAB of the films have decreased by up to 55\% and 30\%, respectively compared to the starch/gum film, therefore the existence of beeswax did not give benefits on improving the mechanical properties. 


\subsection{Modification by Ionic Surfactants}

There are two types of ionic surfactants specifically anionic and cationic surfactants. They are usually employed in solution-based films through the preparation of FFS. Table 5 demonstrates the examples of ionic surfactants, HLB values, alkyl chain length and functional properties of biopolymer-based films. Most of the ionic surfactants such as sodium stearoyl lactate, sodium dodecyl sulfate and ethyl lauroyl arginate $\mathrm{HCl}$ have been used in the preparation of biopolymer-based films $[10,39,49]$. Table 5 also shows that the longer the alkyl chain length is, the lesser the HLB values are, in contrast to non-ionic surfactants. Sodium stearoyl lactate has an HLB value of 8.3, it has longer alkyl chain length than sodium dodecyl sulfate which has an HLB value of 40. In addition, ethyl lauroyl arginate $\mathrm{HCl}$ also has the same alkyl chain length as sodium dodecyl sulfate and it has an HLB value of 16, which is higher compared to sodium stearoyl lactate. On the other hand, sodium stearoyl lactate and sodium dodecyl sulfate were frequently used in the preparation of solution-based films [10,39], whereas ethyl lauroyl arginate $\mathrm{HCl}$ could also be utilized in the creation of both solution- and emulsion-based films $[49,58]$. Therefore, the use of ionic surfactants in the preparation of biopolymer-based films can be associated with their HLB values.

Table 5. Examples of ionic surfactants, HLB values, alkyl chain length and functional properties of biopolymer-based films.

\begin{tabular}{|c|c|c|c|c|c|c|c|c|c|}
\hline Ionic Surfactant & $\begin{array}{l}\text { HLB } \\
\text { Value }\end{array}$ & $\begin{array}{l}\text { Alkyl Chain } \\
\text { Length }\end{array}$ & Biopolymer & $\begin{array}{c}\text { Film- } \\
\text { Forming }\end{array}$ & WVP & TS & EAB & Op & References \\
\hline Sodium stearoyl lactate & 8.3 & $\mathrm{C}_{18}$ & Bovine skin Gelatin & Solution & $\downarrow$ & $\downarrow$ & $\uparrow$ & $\uparrow$ & [39] \\
\hline Ethyl lauroyl arginate $\mathrm{HCl}$ & 16 & $\mathrm{C}_{12}$ & Gelatin & Solution & 小 & $\uparrow$ & $\uparrow$ & $\downarrow$ & [49] \\
\hline Ethyl lauroyl arginate $\mathrm{HCl}$ & 16 & $\mathrm{C}_{12}$ & Chitosan & Emulsion & $\uparrow$ & $\downarrow$ & $\uparrow$ & $\mathrm{n} / \mathrm{a}$ & [58] \\
\hline
\end{tabular}

WVP—water vapor permeability, TS—tensile strength, EAB—elongation at break and Op-opacity; The symbol $\uparrow$ corresponds to an increase in the properties and $\downarrow$ a decrease in the properties while " $\mathrm{n} / \mathrm{a}$ " and $\downarrow \uparrow$ mean "not available" and "unchanged"; respectively.

Table 5 also displays that sodium stearoyl lactate has modified the FFS of bovine skin gelatin in the preparation of the gelatin-based films [39]. The modification by sodium stearoyl lactate has improved the functional properties such as WVP, EAB and Op of the films. The WVP of the films has decreased by up to $68 \%$ compared to the film without sodium stearoyl lactate. This is attributed to the negatively charged hydrophilic part is electrostatically interacted with the positively charged amino acid residues in gelatin [39]. In addition, the EAB of the films has slightly increased by up to $2.6 \%$ due to the presence of interactions between sodium stearoyl lactate and gelatin chains. The Op of the films has slightly increased by up to $8.3 \%$ because sodium stearoyl lactate has caused the component rearrangement in the gelatin film during the drying process. However, the TS of the films has slightly decreased by up to $6.8 \%$ compared to the film without sodium stearoyl lactate, this is common behavior for films with high EAB. On the other hand, sodium dodecyl sulfate has modified the FFS of cassava starch in the preparation of the cassava starch-based films [10]. The modification by sodium dodecyl sulfate has improved the functional properties such as WVP, TS and Op of the films. The WVP of the films has decreased by up to $10 \%$ compared to the film without sodium dodecyl sulfate. This is attributed to the increased interaction between sodium dodecyl sulfate and starch which decreased the free channel for the transit of water vapor. In addition, the TS of the films has significantly increased by up to $1179 \%$ due to sodium dodecyl sulfate could form rigid complexes with amylose and amylopectin of the starch molecular chains with higher rigid and tension [10]. However, the EAB of the films has decreased by up to $39 \%$ because of the tensile strength extremely increased in starch films in the presence of sodium dodecyl sulfate. In addition, the Op of the films has increased by up to $192 \%$ compared to the film without sodium dodecyl sulfate, this is due to sodium dodecyl sulfate and starch have more interactions between molecules, which provided the starch with greater continuity and fewer empty spaces, resulting in a film that blocked more light path [10]. 
Ethyl lauroyl arginate $\mathrm{HCl}$ modifies the FFS of gelatin in the preparation of the gelatin-based films [49]. The modification by ethyl lauroyl arginate $\mathrm{HCl}$ has improved the functional properties such as TS and EAB of the films. The TS of the films has slightly increased by up to $4.3 \%$ compared to the film without ethyl lauroyl arginate $\mathrm{HCl}$. Moreover, the $\mathrm{EAB}$ of the films has also slightly increased by up to $7.5 \%$. The slight increase may be due to the low content of ethyl lauroyl arginate $\mathrm{HCl}$ modified the films [49]. Furthermore, the transparency of the films has slightly increased by up to $6.3 \%$ because of the good compatibility between film components. The higher transparency suggests that the films are less opaque. Nevertheless, the WVP of the films has not been influenced by ethyl lauroyl arginate $\mathrm{HCl}$ [49]. On the other hand, ethyl lauroyl arginate $\mathrm{HCl}$ modifies the FFE of chitosan containing cinnamon oil in the preparation of the emulsified chitosan films [58]. The modification by ethyl lauroyl arginate $\mathrm{HCl}$ has only improved the functional properties such as $\mathrm{EAB}$ of the films. The EAB of the films has increased by up to $169 \%$ compared to the chitosan film. This is attributed to the uniform dispersion of positively charged ethyl lauroyl arginate $\mathrm{HCl}$ compound in the chitosan matrix [58]. However, the TS of the films has significantly decreased by up to $53 \%$ due to the distributed small droplets of cinnamon oil, which have disrupted the chitosan matrix. Moreover, the WVP of the films has decreased by up to $39 \%$ compared to the chitosan film. This is because of the modification by ethyl lauroyl arginate $\mathrm{HCl}$ may split hydrogen bonding and interrupt the ordered structures of chitosan molecules, resulting in the raised WVP of the films [58].

\subsection{Modification by Amphoteric Surfactant}

Amphoteric or zwitterionic surfactants are also ionic surfactants, but they have both negative and positive charges. Soy lecithin or L- $\alpha$-phosphatidylcholine is one of the amphoteric surfactants that has regularly been modified the biopolymer-based films [43]. Soy lecithin is a byproduct of soybean oil processing [27]. The chemical structure of soy lecithin is shown in Figure $2 \mathrm{~h}$, it consists of phosphate and quat groups (hydrophilic head groups) and two fatty acid groups (lipophilic tail groups) [43]. Soy lecithin has an HLB value of 4.0, and it is a predominantly hydrophobic surfactant [34]. It was frequently utilized in preparation of emulsion-based films $[27,31,35,43,60,61]$. Nevertheless, the soy lecithin can also be employed in the creation of solution-based films $[2,28,53]$. Table 6 indicates the functional properties of biopolymer-based films modified with soy lecithin. The biopolymers, for instance, soy protein and fish gelatin have been used for the preparation of emulsion-based films, whereas pig hide gelatin and potato starch utilized for the creation of solution-based films. From Table 6, it can be seen that the modification by soy lecithin has decreased the WVP of the films, this is because the soy lecithin is principally had lipophilic behavior, which could reduce the amount of water vapor to pass through the films. On the other hand, the TS of the films has also decreased with the modification by soy lecithin. However, the presence of soy lecithin has increased the EAB of the films, this is due to soy lecithin has behaved as plasticizer or lubricant in the films, causing an improvement of flexibility and the decrease of TS [27]. In addition, the films modified with soy lecithin also have high Op, especially for emulsion-based films, this is caused by the light-scattering effect of oil droplets, which is distributed throughout the films $[43,61]$.

Table 6. Functional properties of biopolymer-based films modified with soy lecithin.

\begin{tabular}{ccccccc}
\hline Biopolymer & Film-Forming & WVP & TS & EAB & Op & References \\
\hline Soy protein & Emulsion & $\downarrow$ & $\downarrow$ & $\uparrow$ & $\uparrow$ & {$[27]$} \\
Fish gelatin & Emulsion & $\downarrow$ & $\downarrow$ & $\uparrow$ & $\uparrow$ & {$[43]$} \\
Fish gelatin & Emulsion & $\downarrow$ & $\downarrow$ & $\uparrow$ & $\uparrow$ & {$[61]$} \\
Pig hide gelatin & Solution & $\downarrow$ & $\downarrow$ & $\uparrow$ & $\uparrow$ & {$[53]$} \\
Pig hide gelatin & Solution & $\downarrow$ & $\downarrow$ & $\uparrow$ & $\uparrow$ & {$[28]$} \\
Potato starch & Solution & $\downarrow$ & $\downarrow$ & $\uparrow$ & n/a & {$[2]$}
\end{tabular}

WVP-water vapor permeability, TS—-tensile strength, EAB—elongation at break and Op—opacity; The symbol $\uparrow$ corresponds to an increase in the properties and $\downarrow$ a decrease in the properties while " $\mathrm{n} / \mathrm{a}$ " means "not available". 


\section{Conclusions}

Biopolymer raw materials, processing parameters and types of biopolymer-based films modified with surface-active agents (surfactants) have been briefly reviewed in this study. The main functional properties, for example, water vapor permeability, tensile strength, elongation at break and opacity of the films have also been identified in this brief review. Surfactants have frequently modified the biopolymer-based films because they have amphiphilic character. Surfactants employed for different types of biopolymers are mostly based on HLB value and their chemical structures. Non-ionic and amphoteric surfactants have been the two most important surfactants for the biopolymer-based films. Non-ionic surfactants provide a wide range of HLB values and various alkyl chain lengths. An amphoteric surfactant such as soy lecithin is a promising alternative to synthetic surfactants because it is a byproduct of soybean oil processing. It also has the capability to use in both solutionand emulsion-based films. The films modified with soy lecithin have great functional properties such as low water vapor permeability, high flexibility and opacity. This brief review may be useful for the commercialization of bio-based, low-cost, environmentally friendly films for numerous applications.

Author Contributions: Conceptualization, A.A.S. and S.N.A.M.J.; methodology, A.A.S.; validation, A.A.S. and S.N.A.M.J.; formal analysis, S.N.A.M.J.; investigation, A.A.S.; resources, S.N.A.M.J.; data curation, A.A.S.; writing-original draft preparation, A.A.S.; writing-review and editing, S.N.A.M.J.; project administration, A.A.S.; funding acquisition, S.N.A.M.J. All authors have read and agreed to the published version of the manuscript.

Funding: This brief review was funded by the Universiti Putra Malaysia under the Grant Putra IPM Scheme (project number: GP-IPM/2017/9579900).

Acknowledgments: The authors would like to thank the Laboratory of Biocomposite Technology, Institute of Tropical Forestry and Forest Products, Universiti Putra Malaysia.

Conflicts of Interest: The authors declare no conflicts of interest. The funder had no role in the design of the review; in the collection, analyses or interpretation of data; in the writing of the manuscript or in the decision to publish the results.

\section{References}

1. Chen, C.H.; Kuo, W.S.; Lai, L.S. Effect of surfactants on water barrier and physical properties of tapioca starch/decolorized hsian-tsao leaf gum films. Food Hydrocoll. 2009, 23, 714-721. [CrossRef]

2. Rodríguez, M.; Oses, J.; Ziani, K.; Mate, J.I. Combined effect of plasticizers and surfactants on the physical properties of starch based edible films. Food Res. Int. 2006, 39, 840-846. [CrossRef]

3. Bravin, B.; Peressini, D.; Sensidoni, A. Influence of emulsifier type and content on functional properties of polysaccharide lipid-based edible films. J. Agric. Food Chem. 2004, 52, 6448-6455. [CrossRef] [PubMed]

4. Gutiérrez, M.C.; del Carmen Nuñez-Santiago, M.; Romero-Bastida, C.A.; Martinez-Bustos, F. Effects of coconut oil concentration as a plasticizer and Yucca schidigera extract as a surfactant in the preparation of extruded corn starch films. Starch-Staerke 2014, 66, 1079-1088. [CrossRef]

5. Ortega-Toro, R.; Jiménez, A.; Talens, P.; Chiralt, A. Effect of the incorporation of surfactants on the physical properties of corn starch films. Food Hydrocoll. 2014, 38, 66-75. [CrossRef]

6. Song, X.; Zuo, G.; Chen, F. Effect of essential oil and surfactant on the physical and antimicrobial properties of corn and wheat starch films. Int. J. Biol. Macromol. 2018, 107, 1302-1309. [CrossRef]

7. Kowalczyk, D.; Biendl, M. Physicochemical and antioxidant properties of biopolymer/candelilla wax emulsion films containing hop extract-A comparative study. Food Hydrocoll. 2016, 60, 384-392. [CrossRef]

8. Li, J.; Ye, F.; Lei, L.; Zhao, G. Combined effects of octenylsuccination and oregano essential oil on sweet potato starch films with an emphasis on water resistance. Int. J. Biol. Macromol. 2018, 115, 547-553. [CrossRef]

9. Santacruz, S.; Rivadeneira, C.; Castro, M. Edible films based on starch and chitosan. Effect of starch source and concentration, plasticizer, surfactant's hydrophobic tail and mechanical treatment. Food Hydrocoll. 2015, 49, 89-94. [CrossRef]

10. Maniglia, B.C.; Laroque, D.A.; de Andrade, L.M.; Carciofi, B.A.M.; Tenório, J.A.S.; de Andrade, C.J. Production of active cassava starch films; effect of adding a biosurfactant or synthetic surfactant. React. Funct. Polym. 2019, 144, 104368-104374. [CrossRef] 
11. Porras, D.P.N.; Suárez, M.G.; Umaña, J.H.; Perdomo, L.G.P. Optimization of physical, optical and barrier properties of films made from cassava starch and rosemary oil. J. Polym. Environ. 2019, 27, 127-140. [CrossRef]

12. Chen, C.H.; Kuo, W.S.; Lai, L.S. Water barrier and physical properties of starch/decolorized hsian-tsao leaf gum films: Impact of surfactant lamination. Food Hydrocoll. 2010, 24, 200-207. [CrossRef]

13. Trezza, T.A.; Krochta, J.M. The gloss of edible coatings as affected by surfactants, lipids, relative humidity, and time. J. Food Sci. 2000, 65, 658-662. [CrossRef]

14. Rodríguez-Castellanos, W.; Martínez-Bustos, F.; Jiménez-Arévalo, O.; González-Núñez, R.; Galicia-García, T. Functional properties of extruded and tubular films of sorghum starch-based glycerol and Yucca Schidigera extract. Ind. Crop. Prod. 2013, 44, 405-412. [CrossRef]

15. Cao, T.L.; Song, K.B. Effects of gum karaya addition on the characteristics of loquat seed starch films containing oregano essential oil. Food Hydrocoll. 2019, 97, 105198-105206. [CrossRef]

16. Zhong, Y.; Li, Y. Effects of surfactants on the functional and structural properties of kudzu (Pueraria lobata) starch/ascorbic acid films. Carbohydr. Polym. 2011, 85, 622-628. [CrossRef]

17. Saberi, B.; Chockchaisawasdee, S.; Golding, J.B.; Scarlett, C.J.; Stathopoulos, C.E. Development of biocomposite films incorporated with different amounts of shellac, emulsifier, and surfactant. Food Hydrocoll. 2017, 72, 174-184. [CrossRef]

18. Han, Y.; Yu, M.; Wang, L. Physical and antimicrobial properties of sodium alginate/carboxymethyl cellulose films incorporated with cinnamon essential oil. Food Packag. Shelf Life 2018, 15, 35-42. [CrossRef]

19. Martelli, S.M.; Motta, C.; Caon, T.; Alberton, J.; Bellettini, I.C.; do Prado, A.C.P.; Barreto, P.L.M.; Soldi, V. Edible carboxymethyl cellulose films containing natural antioxidant and surfactants: $\alpha$-tocopherol stability, in vitro release and film properties. LWT 2017, 77, 21-29. [CrossRef]

20. Lian, H.; Peng, Y.; Shi, J.; Wang, Q. Effect of emulsifier hydrophilic-lipophilic balance (HLB) on the release of thyme essential oil from chitosan films. Food Hydrocoll. 2019, 97, 105213-105220. [CrossRef]

21. Ma, Q.; Zhang, Y.; Critzer, F.; Davidson, P.M.; Zivanovic, S.; Zhong, Q. Physical, mechanical, and antimicrobial properties of chitosan films with microemulsions of cinnamon bark oil and soybean oil. Food Hydrocoll. 2016, 52, 533-542. [CrossRef]

22. Peng, Y.; Wang, Q.; Shi, J.; Chen, Y.; Zhang, X. Optimization and release evaluation for tea polyphenols and chitosan composite films with regulation of glycerol and Tween. Food Sci. Technol. 2019, 40, 162-170. [CrossRef]

23. Peng, Y.; Li, Y. Combined effects of two kinds of essential oils on physical, mechanical and structural properties of chitosan films. Food Hydrocoll. 2014, 36, 287-293. [CrossRef]

24. Ziani, K.; Oses, J.; Coma, V.; Maté, J.I. Effect of the presence of glycerol and Tween 20 on the chemical and physical properties of films based on chitosan with different degree of deacetylation. LWT-Food Sci. Technol. 2008, 41, 2159-2165. [CrossRef]

25. Andreuccetti, C.; Carvalho, R.A.; Galicia-García, T.; Martinez-Bustos, F.; González-Nuñez, R.; Grosso, C.R. Functional properties of gelatin-based films containing Yucca schidigera extract produced via casting, extrusion and blown extrusion processes: A preliminary study. J. Food Eng. 2012, 113, 33-40. [CrossRef]

26. Bahram, S.; Rezaei, M.; Soltani, M.; Kamali, A.; Ojagh, S.M.; Abdollahi, M. Whey protein concentrate edible film activated with cinnamon essential oil. J. Food Process. Preserv. 2014, 38, 1251-1258. [CrossRef]

27. Carpiné, D.; Dagostin, J.L.A.; Bertan, L.C.; Mafra, M.R. Development and characterization of soy protein isolate emulsion-based edible films with added coconut oil for olive oil packaging: Barrier, mechanical, and thermal properties. Food Bioprocess Technol. 2015, 8, 1811-1823. [CrossRef]

28. Dias, T.P.; Grosso, C.R.; Andreuccetti, C.; Carvalho, R.A.D.; Galicia-García, T.; Martinez-Bustos, F. Effect of the addition of soy lecithin and Yucca schidigera extract on the properties of gelatin and glycerol based biodegradable films. Polimeros 2013, 23, 339-345. [CrossRef]

29. Limpisophon, K.; Tanaka, M.; Osako, K. Characterisation of gelatin-fatty acid emulsion films based on blue shark (Prionace glauca) skin gelatin. Food Chem. 2010, 122, 1095-1101. [CrossRef]

30. Pereira, G.V.D.S.; Pereira, G.V.D.S.; Neves, E.M.P.X.; Joele, M.R.S.P.; Lourenço, L.D.F.H. Effect of adding fatty acids and surfactant on the functional properties of biodegradable films prepared with myofibrillar proteins from acoupa weakfish (Cynoscion acoupa). Food Sci. Technol. 2019, 39, 287-294. [CrossRef] 
31. Tongnuanchan, P.; Benjakul, S.; Prodpran, T. Structural, morphological and thermal behaviour characterisations of fish gelatin film incorporated with basil and citronella essential oils as affected by surfactants. Food Hydrocoll. 2014, 41, 33-43. [CrossRef]

32. Andreuccetti, C.; Carvalho, R.A.; Galicia-García, T.; Martínez-Bustos, F.; Grosso, C.R. Effect of surfactants on the functional properties of gelatin-based edible films. J. Food Eng. 2011, 103, 129-136. [CrossRef]

33. Łupina, K.; Kowalczyk, D.; Zięba, E.; Kazimierczak, W.; Mężyńska, M.; Basiura-Cembala, M.; Wiącek, A.E. Edible films made from blends of gelatin and polysaccharide-based emulsifiers-A comparative study. Food Hydrocoll. 2019, 96, 555-567. [CrossRef]

34. Nilsuwan, K.; Benjakul, S.; Prodpran, T. Properties, microstructure and heat seal ability of bilayer films based on fish gelatin and emulsified gelatin films. Food Biophys. 2017, 12, 234-243. [CrossRef]

35. Tongnuanchan, P.; Benjakul, S.; Prodpran, T.; Pisuchpen, S.; Osako, K. Mechanical, thermal and heat sealing properties of fish skin gelatin film containing palm oil and basil essential oil with different surfactants. Food Hydrocoll. 2016, 56, 93-107. [CrossRef]

36. Xiao, J.; Wang, W.; Wang, K.; Liu, Y.; Liu, A.; Zhang, S.; Zhao, Y. Impact of melting point of palm oil on mechanical and water barrier properties of gelatin-palm oil emulsion film. Food Hydrocoll. 2016, 60, 243-251. [CrossRef]

37. Hanani, Z.N.; Husna, A.A. Effect of different types and concentrations of emulsifier on the characteristics of kappa-carrageenan films. Int. J. Biol. Macromol. 2018, 114, 710-716. [CrossRef]

38. Shojaee-Aliabadi, S.; Hosseini, H.; Mohammadifar, M.A.; Mohammadi, A.; Ghasemlou, M.; Hosseini, S.M.; Khaksar, R. Characterization of $\mathrm{k}$-carrageenan films incorporated plant essential oils with improved antimicrobial activity. Carbohydr. Polym. 2014, 101, 582-591. [CrossRef]

39. Chambi, H.; Grosso, C. Effect of surfactants on the functional properties of gelatin-Polysaccharide-based films. Eur. Food Res. Technol. 2011, 232, 63-69. [CrossRef]

40. Saurabh, C.K.; Gupta, S.; Variyar, P.S.; Sharma, A. Effect of addition of nanoclay, beeswax, tween-80 and glycerol on physicochemical properties of guar gum films. Ind. Crop. Prod. 2016, 89, 109-118. [CrossRef]

41. Chu, Y.; Xu, T.; Gao, C.; Liu, X.; Zhang, N.; Feng, X.; Liu, X.; Shen, X.; Tang, X. Evaluations of physicochemical and biological properties of pullulan-based films incorporated with cinnamon essential oil and Tween 80. Int. J. Biol. Macromol. 2019, 122, 388-394. [CrossRef]

42. Davanco, T.; Tanada-Palmu, P.; Grosso, C. Composite films made with gelatin, tracetin, stearic and caproic acids: Effect of $\mathrm{pH}$ and surfactants addition on the functionality of films. Cienc. E Tecnol. Aliment. 2007, $27,408-416$.

43. Nilsuwan, K.; Benjakul, S.; Prodpran, T. Emulsion stability and properties of fish gelatin-based films as affected by palm oil and surfactants. J. Sci. Food Agric. 2016, 96, 2504-2513. [CrossRef] [PubMed]

44. Carpiné, D.; Dagostin, J.L.A.; de Andrade, E.F.; Bertan, L.C.; Mafra, M.R. Effect of the natural surfactant Yucca schidigera extract on the properties of biodegradable emulsified films produced from soy protein isolate and coconut oil. Ind. Crop. Prod. 2016, 83, 364-371. [CrossRef]

45. Panzarasa, G.; Osypova, A.; Sicher, A.; Bruinink, A.; Dufresne, E.R. Controlled formation of chitosan particles by a clock reaction. Soft Matter 2018, 14, 6415-6418. [CrossRef] [PubMed]

46. Debeaufort, F.; Voilley, A. Effect of surfactants and drying rate on barrier properties of emulsified edible films. Int. J. Food Sci. Technol. 1995, 30, 183-190. [CrossRef]

47. Villalobos-Carvajal, R.; Hernández-Muñoz, P.; Albors, A.; Chiralt, A. Barrier and optical properties of edible hydroxypropyl methylcellulose coatings containing surfactants applied to fresh cut carrot slices. Food Hydrocoll. 2009, 23, 526-535. [CrossRef]

48. Pattanayaiying, R.; Aran, H.; Cutter, C.N. Optimization of formulations for pullulan films containing lauric arginate and nisin Z. LWT-Food Sci. Technol. 2015, 63, 1110-1120. [CrossRef]

49. Haghighi, H.; De Leo, R.; Bedin, E.; Pfeifer, F.; Siesler, H.W.; Pulvirenti, A. Comparative analysis of blend and bilayer films based on chitosan and gelatin enriched with LAE (lauroyl arginate ethyl) with antimicrobial activity for food packaging applications. Food Packag. Shelf Life 2019, 19, 31-39. [CrossRef]

50. Peng, Y.; Yin, L.; Li, Y. Combined effects of lemon essential oil and surfactants on physical and structural properties of chitosan films. Int. J. Food Sci. Technol. 2013, 48, 44-50. [CrossRef]

51. Villalobos, R.; Hernández-Muñoz, P.; Chiralt, A. Effect of surfactants on water sorption and barrier properties of hydroxypropyl methylcellulose films. Food Hydrocoll. 2006, 20, 502-509. [CrossRef] 
52. Ali, M.; Khan, N.R.; Basit, H.M.; Mahmood, S. Physico-chemical based mechanistic insight into surfactant modulated sodium Carboxymethylcellulose film for skin tissue regeneration applications. J. Polym. Res. 2020, 27, 20. [CrossRef]

53. Andreuccetti, C.; Carvalho, R.A.; Grosso, C.R. Effect of hydrophobic plasticizers on functional properties of gelatin-based films. Food Res. Int. 2009, 42, 1113-1121. [CrossRef]

54. Salarbashi, D.; Tajik, S.; Ghasemlou, M.; Shojaee-Aliabadi, S.; Noghabi, M.S.; Khaksar, R. Characterization of soluble soybean polysaccharide film incorporated essential oil intended for food packaging. Carbohydr. Polym. 2013, 98, 1127-1136. [CrossRef] [PubMed]

55. Kowalczyk, D.; Baraniak, B. Effect of candelilla wax on functional properties of biopolymer emulsion films-A comparative study. Food Hydrocoll. 2014, 41, 195-209. [CrossRef]

56. Kowalczyk, D.; Kordowska-Wiater, M.; Sołowiej, B.; Baraniak, B. Physicochemical and antimicrobial properties of biopolymer-Candelilla wax emulsion films containing potassium sorbate-A comparative study. Food Bioprocess Technol. 2015, 8, 567-579. [CrossRef]

57. Nilsuwan, K.; Benjakul, S.; Prodpran, T. Quality changes of shrimp cracker covered with fish gelatin film without and with palm oil incorporated during storage. Int. Aquat. Res. 2016, 8, 227-238. [CrossRef]

58. Ma, Q.; Zhang, Y.; Zhong, Q. Physical and antimicrobial properties of chitosan films incorporated with lauric arginate, cinnamon oil, and ethylenediaminetetraacetate. LWT-Food Sci. Technol. 2016, 65, 173-179. [CrossRef]

59. Villalobos, R.; Chanona, J.; Hernández, P.; Gutiérrez, G.; Chiralt, A. Gloss and transparency of hydroxypropyl methylcellulose films containing surfactants as affected by their microstructure. Food Hydrocoll. 2005, 19, 53-61. [CrossRef]

60. Nilsuwan, K.; Benjakul, S.; Prodpran, T. Effects of soy lecithin levels and microfluidization conditions on properties of fish gelatin-based film incorporated with palm oil. Int. J. Food Eng. 2016, 12, 647-660. [CrossRef]

61. Tongnuanchan, P.; Benjakul, S.; Prodpran, T. Characteristics and antioxidant activity of leaf essential oil-incorporated fish gelatin films as affected by surfactants. Int. J. Food Sci. Technol. 2013, 48, 2143-2149. [CrossRef]

(C) 2020 by the authors. Licensee MDPI, Basel, Switzerland. This article is an open access article distributed under the terms and conditions of the Creative Commons Attribution (CC BY) license (http://creativecommons.org/licenses/by/4.0/). 